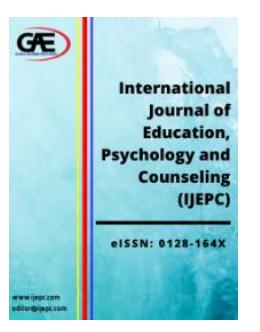

\author{
International Journal of Education, \\ Psychology and Counselling (IJEPC) \\ Journal Website: http://ijepc.com/ \\ eISSN: 0128-164X
}

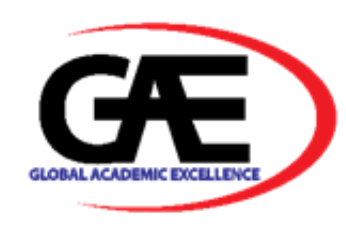

\title{
THE IMPACT OF COOPERATIVE LEARNING METHOD ON YEMENI ADULT STUDENTS' KNOWLEDGE OF GLOBAL ISSUES VOCABULARY
}

\author{
Lamis Abdulkarim Al-Shuga'a ${ }^{1 *}$, Kamariah Yunus ${ }^{2}$, Mohammed Abdulgalil Abugohar $^{3}$ \\ 1 Centre of English Language Studies, Faculty of Languages and Communication, Sultan Zainal Abidin University \\ (UniSZA), Terengganu, Malaysia \\ Email: 1shogaa77@gmail.com \\ 2 Faculty of Languages and Communication, Universiti Sultan Zainal Abidin (UniSZA), Terengganu, Malaysia \\ Email: kamariah@unisza.edu.my \\ 3 Faculty of Languages and Communication, Universiti Sultan Zainal Abidin (UniSZA), Terengganu, Malaysia \\ Email: modyjau@yahoo.com \\ * Corresponding Author
}

\section{Article Info: \\ Article history: \\ Received date: 12.02 .2020 \\ Revised date: 18.02 .2020 \\ Accepted date: 20.02.2020 \\ Published date: 15.03.2020}

\section{To cite this document:}

Al-Shuga'a, L. A., Yunus, K., \& Abugohar, M. A. (2020). The Impact of Cooperative Learning Method on Yemeni Adult Students' Knowledge Of Global Issues Vocabulary. International Journal of Education, Psychology and Counseling, 5 (34), 102-115.

DOI: $10.35631 / \mathrm{IJEPC} .534008$.

\begin{abstract}
:
The cooperative learning method is one of the most effective student-centered learning methods used in teaching English language classes. It is an updated and effective pedagogic method that should be integrated into classrooms. The previously reviewed studies showed that the use of cooperative learning method may improve students' knowledge of the language. This paper aims at investigating the impact of cooperative learning methods on Yemeni adult students' knowledge of global issues vocabulary. The study employed an experimental method research design where the quantitative data collection method was conducted. A pretest and posttest (of the same test) were administered to the 25 respondents in the experimental group and the other 25 respondents in the control group. The Statistical Package for Social Sciences (SPSS) version 25.0 was used to analyse the difference between the two groups' performance using the t-test. Results showed that the students in the experimental group performed significantly better than the students in the comparison group in the required tasks relating to global issues vocabulary knowledge. Findings also indicated that the cooperative learning method had positive effects on students' vocabulary knowledge in classrooms. The participants gained confidence and their language skills were improved. Social skills like leadership, decision-making, trust-building, communication, and conflict-management skills were also developed. The study concludes that cooperative learning contributes to cognitive growth, increased autonomy and productivity of adult learners. The cooperative learning method should be integrated into English language classrooms to improve the growth and
\end{abstract}


productive knowledge of students at the tertiary level.

Keywords:

Student-Centred Learning Methods, Cooperative Learning Method, Global Issues, Vocabulary Knowledge, English Language Teaching (ELT)

\section{Introduction}

Teaching English demands different ways, appreciable experiences, great efforts, etc., and the methods of teaching English should be suitable and manageable based on the varying factors including the course, lessons, skills, exercises, and the needs of the students themselves. Regardless of the curriculum's worthiness, teachers play a crucial and active role in teaching. They are advised to use different techniques and develop methods that in turn will enhance the students' learning process. Lee (2018) asserted that teachers should be well qualified to produce quality learners. A professional teacher should connect matters outside the classroom with the course inside the classroom during teaching.

The world around us faces different worrying problems such as terrorism, ethnic clash, social discrepancy, and environmental destruction. Such problems, and more others, are defined as global issues. Teaching a language in a global context is pedagogically important for the students. Indeed, those problems might not be around us or far from our surroundings but our efforts to introduce our students to the issues happening all over the world may have a substantial impact on the development of the world and the students' knowledge. Sciamarelli (2017) contended that her students do not just need to master a language, but also the knowledge and skills to try to solve some global issues. The researcher also observed that students face difficulty in understanding the vocabulary of global issues which, in turn, leads to difficulty in acquiring the vocabulary of global issues and achieving the required tasks. In fact, teaching the topics of global issues needs suitable methods, techniques and different exercises to facilitate the acquisition of global issues vocabulary. Besides, English teachers at the same time often face the difficulty of choosing the appropriate teaching methods to overcome difficulties that their adult learners face, especially in Yemen, where English is treated as a foreign language.

EFL teachers employ different methods and techniques in teaching vocabulary in language classrooms. Among the methods that are considered to suit teaching vocabulary is the corporation of cooperative learning method, which is one of the most effective studentcentred learning methods used in teaching English language classes. In addition, it is an updated and effective pedagogic process that should be integrated into classrooms. It refers to a particular set of classroom techniques that foster learner interdependence as a route to cognitive and social improvement. Oxford (2014) reported that several studies referred that cooperative learning is more effective in promoting students' motivation and task achievement. It also improves higher-level thinking skills and students' attitudes toward the subject.

Some cooperative learning techniques which improve students' knowledge of the language are jigsaw, semantic maps, word wizard, word connect, concept cube, number heads, thinkpair-share, round-robin, three-step interview, three-minute review, talking chips and write 
around (Mandal, 2011). In this study, the jigsaw technique was used since it is one of the earliest cooperative learning methods and the best motivational devices.

Despite the importance of introducing global issues vocabulary lessons to students, Yemeni learners at the tertiary level still face difficulty in learning and understanding them, and in achieving the required tasks. Having knowledge of using particular and suitable methods in teaching the vocabulary of global issues may improve students' knowledge efficiently. However, to what extent is the method effective? This study aims, therefore, at investigating the impact of cooperative learning method on Yemeni adult students' knowledge of global issues vocabulary. It intends to help Yemeni adult students with serious problems of a lack of engagement in the required tasks. Thus, the question of this study can be stated as:

'How much do the students in the experimental group differ from those in the control group in terms of their overall performance?'

\section{Literature Review}

Erfiani and Neno (2018) affirmed that the jigsaw technique could improve students' vocabulary ability and develop students' interaction with their teacher and other students in the classroom. It was also asserted that the jigsaw technique is one of the most useful cooperative techniques, that lead students to be interested in learning vocabulary lectures. It could motivate and encourage students to be active and had significant participation in learning vocabulary during the teaching and learning process in the classroom.

Nation (2011) has realized that the acquisition of vocabulary is vital for successful FL use. It plays an important role in the formation of complete spoken and written texts. In English, learning vocabulary items also plays an essential role in all language skills. Additionally, it was asserted that vocabulary knowledge is essential because readers/listeners should be flexible in applying suitable meaning to the word(s) based upon the context. With some knowledge of vocabulary, language production and language comprehension would be possible. Thus, the growth of vocabulary knowledge is one of the essential matters for language acquisition and this growth of vocabulary knowledge can be achieved successfully when teachers employ effective vocabulary teaching and learning methods as cooperative learning methods. According to Nation (2001), the different aspects of a word or vocabulary can be generally referred to as vocabulary knowledge. For him, one significant feature of word knowledge is the use of words. That is to say, while learning a new word, L2/FL learners must know how a word is used. Nation (2001) described the relationship between vocabulary knowledge and language use as a complementary process. That is to say, knowledge of vocabulary enables language use and, conversely; language use leads to an improvement in vocabulary knowledge for students. What constitutes the use of words is grammatical functions, collocations and constraints on use.

On the other hand, Schmitt (2008) claimed that to master new vocabulary and besides needing a large number of lexical items, a learner should know more about each item in order to use it well. In fact, this is referred to as the quality of vocabulary knowledge. It is not enough to consider a word learned if only the spoken or written form and meaning are known. However, to use the word productively a learner must gain more knowledge about this specific lexical item, and this is the objective of this study regarding the vocabulary of global issues so that the outcome is the language development of the students. 
Concerning to language development, Daloğu (2010) affirmed that there are close relationships between cooperative learning and language development. Thus, learners who are taught through cooperative learning may be exposed to increased amounts of effective communication in both comprehension and production, using the language for academic and social functions. Moreover, students' performance in fulfilling the required tasks is improved gradually. Bilen (2015) asserted that education is a tool for students to learn how to participate in classrooms cooperatively. He believes that education plays a significant role in exercising and embellishing cooperative learning method as a means of promoting students' socialization, as well as motivation and task achievement. In addition, Oxford (2014) believes that cooperative learning may improve higher-level thinking skills and students' attitudes toward the subject. Unlike the traditional method, the cooperative learning method increases achievement and time on task, generates self-esteem, improves academic peer norms and takes advantage of learner diversity in the classroom.

According to Yavuz and Arslan, (2018), cooperative learning creates a non-stressful environment both for learning and practising English vocabulary, and it helps learners to learn and participate in collaboration, have fun and improve their language skills in an integrated way. In addition, student-student interaction allows them to build healthy relationships with each other and take more responsibility to be active participants in the classroom. This kind of intimacy in learning and relaxed atmosphere motivates the learners to practice the language communicatively. While studying in groups, they have the chance to make requests, explanations, suggestions, agree/disagree and clarification of any inquiries relating to learning the vocabulary of global issues.

So, in learning global issues lessons, students will be skilful to interpret information, develop critical thinking, and choose appropriate ways and approaches for solving world problems. They can communicate efficiently to express their ideas, views and opinions. Research skills and media literacy are going to be developed, too. Through learning global issues, awareness and senses of a shared global citizenship will be improved gradually. Besides, it will be able to outline the challenges, dilemmas and conflicts of values that are decided, to reflect upon one's own values and to consider rules and principles to integrate as a citizen and in one's future career.

Lopes (2012) identified some outcomes which are applied across curricula in learning world problems. Four main outcomes are established, including knowledge, skills, values, and taking action. Erfani (2012) construes that "due to the importance of textbooks in any ELT context it is necessary to consider all aspects of global issues not only in materials development but also in course design and methods of teaching" (p. 2415).

In fact, the use of cooperative learning method may improve students' knowledge of the global issues vocabulary. AlMashjari (2012) found that cooperative learning method employed in the newly developed high school system in her country enhanced the students' English proficiency as measured by their abilities in grammar, reading comprehension, vocabulary, and listening comprehension. The study also measured the participants' attitudes towards cooperative learning and their motivation to learn English in the new high school system. It was found that cooperative learning in the new system positively affects some aspects of the respondents' English proficiency and they had a positive attitude towards cooperative learning in the new system and a higher motivation to learn English. 
Almulla (2017) investigated the perceptions of Saudi high school teachers and their students about cooperative learning. It also investigates teachers' classroom practices based on the five cooperative learning principles (Johnson \& Johnson, 2014). The findings of the study indicate that all teachers and the majority of students in this investigation presented positive attitudes towards cooperative learning and prefer it to the lecture-style lesson (teacher-centred learning). The findings suggest that training in cooperative learning is significant to help teachers change their practice and their perceptions of classroom roles, responsibility, and authority as well. Terry (2018) also conducted a study on the importance of respondents' engagement in cooperative learning activates. The findings showed that behavioural, emotional, and cognitive student' engagement through cooperative learning activities improved academic achievement, especially of vocabulary and grammar.

Ünal (2008) observed that teacher education about environmental problems should be improved to increase students' awareness and knowledge about local and global environmental issues. The results indicated that a large number of Elementary Education preservice teachers granted more significance to global environmental issues and global education should be integrated into classrooms. The study recommended that operative environmental courses be improved from primary to higher education in order to develop students' environmental knowledge.

Another study that is related to the importance of global education in classrooms was carried out by Inka and Niina (2013). They believed that global education is a very important activity that guides students to have knowledge about world issues and to become responsible world citizens. Consequently, teachers should be aware of the significance of global education to transfer their knowledge to students. The essential aim of the study was to find out Finnish elementary school teachers' perceptions, experiences and attitudes toward global education. The other aims of the study were to explore the kind of resources that teachers have for implementing global education and how to improve global education services and materials offered to elementary schools. The results of the study revealed that teachers generally realize the necessity of integrating global education as a branch of education. They also agreed that global education should be incorporated into the teacher-training program as an individual subject in order to increase the level of global education. It was added that global education services and materials should be more available. So that teachers can find them easily and without wasting time.

Cooperative learning contributes to cognitive growth since it is based on important cognitive theories as Vygotskian, Piagetian, and Banduran learning theories and that have supported the theories that were used to underpin this research; namely, Vygotsky's (1978) socio-cultural scaffolding theory and Graves and Slater's (1987) schema theory. These theories are based upon the independent variable of the study (cooperative learning method) and the dependent variable (vocabulary productive knowledge). In the intervention phase of this study, it was observed that cooperative learning made students feel more motivated, interested and encouraged and the classroom had a relaxed and comfortable atmosphere. Group work is more effective and significant than individual work, consequently, the members felt free to express their opinions and ideas and respect each other. That claim is supported by Vygotsky's (1978) perspective about teaching and its relationship with the external world. For him, cultures with different conceptual categories should be expected to perceive and 
therefore to think about the world differently from other cultures. In addition, Vygotsky (1962) outlined that students' learning is a result of social and dyadic interactions; that is to interact with more knowledgeable people (teachers, parents, peers) and fulfil some cultural tasks. Thus, the learning process is facilitated. Additionally, students' cognitive improves since their thinking is related to society in the form of sharing social activities with people who are surrounding them (Shabani, 2016). Ellis and Barkhuizen (2005) confirmed that, through scaffolding, learners are able to be in a progress level than they can attain by themselves. They added that it is significant to notice that ZPD (Zone of Proximal Development) is conceptualized as something that emerges through participation in collaborative activities, not as an attribute of learners (as cited in Allahyar \& Nazari, 2012).

On the other hand, Samuels (1994) argues that the importance of schema theory to comprehension lies in how the learners use schemata. He emphasizes that the internal aspects of attention (to process information) is crucial to comprehension and defines three characteristics of internal attention. First is alertness. It is the learners' active attempt to access relevant schemata involving not only letter-sound relationships, syntactic knowledge but also word meanings. The second is selectivity. It refers to the learners' ability to attend selectively to only that information which requires processing. The last characteristic is of limited capacity. It refers to the fact that learners' brain has limited cognitive energy for processing information purposes. To clarify the idea of schema theory, Margana (2016) states that learners develop schemata through experience and schemata does not only affect the way information is interpreted but also continues to change as new information is received to facilitate further comprehension. This statement is supported by Graves and Slater (1987) who asserted that learners can easily learn new words (as global issues words) if they have the schemata for the exposure of suitable method for learning (as cooperative learning methods). Jahromi and Marzban (2015) asserted that finding an appropriate way to learn vocabulary is a crucial issue in acquiring them. So, cooperative learning methods can help students learn and recall new vocabulary. Hence, the aforementioned theories underpin the present research, supporting and enriching it with information in which the objectives of this research can be achieved, and research questions can be answered.

Klapwijk (2015) strongly stands up teachers for introducing strategies (such as the cooperative learning methods used in this study, namely, the jigsaw technique and monolingual dictionary, English - English) in the form of explicit instruction. Therefore, learners have the ability to think of the process of learning the needed meaning when they face difficult words or texts. The jigsaw technique is one of the earliest cooperative learning methods and the best motivational devices used to create a real 'information gap' in the classroom and encourage communication. Moreover, Falchikov (2001) asserted that there are two main aims of the jigsaw method. Firstly, it is to enhance pre-service teacher preparation through cooperation and, secondly, to develop learners' academic and social learning (Azzioui, 2016). Hausfather (1996) maintained that teachers must engage students' interest and simplify the tasks, so they are controlled and manageable. Teachers should also motivate learners to fulfil the instructional goal (improving their vocabulary of global issues and language acquisition).

To clarify the steps of applying jigsaw technique in classrooms, the students are divided into groups ( $3-4$ students as a maximum). Their teacher should distribute duties among the groups who should have an idea about what they are going to do. The students discussed the 
required topic with other students from other teams who also get similar information on the topic given as a part of the Jigsaw method. Each member in a group is responsible for learning a particular part of a global issue text (their teacher determines) and translate the new words using English-English dictionaries. Then they teach those words to another group (called expert groups, i. e. learners who are holding the same information). They can introduce definitions of some new words in their own words and can also ask their teachers for help. After that, each group member comes back to his/her home groups. During this process, the learners exchange ideas, brainstorm and discuss the given topic based on the information they have collected from the expert teams. They combine their knowledge to fill in the information gaps and teach their peers what they have learned. Each group member can copy the translation of the new word and their definitions that they learn from each member in their notebooks. So, the topic is discussed and new words are understood very well. At the end of the lesson, all learners take a quiz/activity about the whole topic to evaluate their work and to keep the new vocabulary of global issues. Teachers should guide and monitor the progress, explaining and answering questions that students may ask (Slavin, 1995).

Simply, to go deeper into the jigsaw technique concept, suppose that a class consists of 16 students. They are divided into four groups. Each group is 1, 2, 3 and 4. '1s' come together and concentrate on their part, discussing the new words. ' $2 \mathrm{~s}, 3 \mathrm{~s}$ and $4 \mathrm{~s}$ ' do the same thing. Then, group members $(1,2,3$, and 4) come back to their home groups, combine their knowledge to fill in the information gaps, and teach their peers what they have learned. To have the teacher's role means you have to prepare very well, to keep many words in your mind and to make sure that students understand everything very well. As a result, you are able to achieve the required tasks and activities confidently.

In cooperative learning, students may need to use some strategies and techniques to help in the learning process in the classroom. Gairns and Redman (1986) demonstrate a list of these techniques that students need for dealing with skills and activities when learning new vocabularies, such as asking others, using a dictionary, and contextual guesswork. Thus, it was chosen using a monolingual dictionary (English - English) as a second technique to help the participants of this study to improve their knowledge of English language vocabulary.

Pratama and Yuliati (2016) declared that students need to master the skills of communication, critical and logical thinking, creativity, and problem-solving. That cannot be achieved efficiently unless the students learn vocabulary, including the vocabulary of global issues. Thus, they can express their thoughts, ideas, experiences, and feeling. In addition, Sciamarelli (2017) claimed that teaching global issues in the classroom is imperative because that gives students a chance to communicate and express their views, transforms the classroom into a real-life environment creating internationally aware students.

\section{Methodology}

The study employed an experimental research design where quantitative data were utilized to collect data. A pre-test and post-test (of the same test) were introduced to the experimental and control groups, comprising 25 respondents in each. For the pre-test/post-test (inferential statistics), independent samples $t$-test was used. The independent variable of the study is cooperative learning method and the dependent variable is vocabulary productive knowledge. 
The population of the study constitutes English language students at MALI private institute in Taiz, Yemen. The sample was selected using a purposive sampling method since there are two levels of students in the institute, adult and beginners. Adult students were recruited as a sample for their opinions about the issue were more attainable. 25 students (both males and females) were placed in the experimental group and the other 25 students were placed in the control group. 50 students participating in experimental research surpassed the minimum size of including 15 students in the group of an experimental study (Dornyei, (2007).

The research instrument in the form of pretest/posttest was designed specifically to examine the impact of cooperative learning method on the students' vocabulary knowledge to answer the research questions. Dimitrov and Rumrill (2014) confirmed that pretest-posttest designs are widely used in behavioural research, primarily to compare groups and/or measuring change resulting from experimental treatments. An intervention phase took place for two hours a day (a period only), for seven weeks, totalling 40 hours altogether. Both groups (50 participants) studied 8 global issues lessons, which were selected by the researcher. Those global issues lessons are poverty, hurricane, flooding, injustice, human rights, unemployment, overpopulation and air pollution.

The treatment group was taught global issues lessons using the selected cooperative learning method (the jigsaw technique and using a monolingual dictionary, English - English), whereas the control group was taught global issues lessons using traditional techniques as translation into the target language, definitions, and so on (teacher-centred learning).

The students in the experimental group were given several tasks during the experimental design. The task included $4-6$ questions, which the experimental group had to answer them cooperatively at the end of each global issue lesson. When they answered the questions in the required tasks, the group should help and explain to each other difficult things concerning the vocabulary of the global issue of that lesson. The role of the teacher was just as a guide. For the control group, they were given several tasks as well. The task included $4-6$ questions which they had to answered them individually. In this group, the teacher had the main role in the classroom since it was used as a traditional method. The duration of the time given for them to complete the required tasks was the same for both groups, i. e., $10-15$ minutes.

The pretest/posttest items were divided into five sections, comprising sentence completion ( 8 items worth 8 marks), gap-filling ( 8 items worth 8 marks), direct questions ( 8 items worth 8 marks), sentence production (4 items worth 8 marks), and writing exercises (4 items worth 8 marks). The total mark is 40 , and the duration of the test is two hours. All scores of the pretest/posttest were keyed-in using the SPSS software version 25.0, and the independent samples $t$-test (a parametric test) was used to analyse the data.

\section{Results and Discussion}

As displayed below in Table 1, the results indicated that there is a significant difference in the overall score of the test between the experimental and the control group ( $p$-value $=.000$ which is $<0.05)$. By comparing the two mean ranks of the experimental and control groups, it was evident that the mean rank value of the experimental group (mean rank $=12.92$ ) was greater than the mean rank value of the control group (mean rank $=5.32$ ). This clearly showed that the experimental group performed significantly better than the control group in 
the required tasks. The participants gained confidence and their language skills were improved.

Table 1: The Overall Score of the Test

\begin{tabular}{lcll}
\hline Group & $\mathbf{N}$ & Mean Rank & $\boldsymbol{p}$-value \\
\hline Control & 25 & 5.32 & .000 \\
\hline Experimental & 25 & 12.92 & .000 \\
\hline
\end{tabular}

Cooperative learning increases achievement and time on task, generates self-esteem, improves academic peer norms, and takes advantage of learner diversity in the classroom. That is because each learner has a different learning style, interest, and talent in classrooms. In other words, teaching the vocabulary of global issues cooperatively had a significant impact on experimental students' vocabulary knowledge because student-centred classes are more effective than teacher-centred classes since student-centred classes focus on the learning itself, not the teaching. In this way, students were responsible for their own learning independently according to their individual needs and styles. Additionally, they were more motivated to learn a foreign language. The same significant finding of the study was also reported in Slavin's (1995), Johnson and Johnson's (1999), Kagan's (1999), Richards and Rodgers' (2001), AlMashjari's (2012), Oxford's (2014), Jiang's (2014), Almulla's (2017) and Terry's (2018) studies.

Regarding cooperative learning method, Alrayah (2018) reported that each member of the group team is responsible not only for learning what is required but also for helping teammates learn. So, they can create an effective environment of achievement and practice. Moreover, cooperative learning requires that learners appropriately use interpersonal and small-group skills.

Unlike traditional learning environments in which the students are not sufficiently aware of each other, the attitude that may arise as a result of the interaction among them does not improve positively; whereas, in teamwork, it is possible to improve positive attitudes and perceptions about vocabulary knowledge based on interaction and common success between the team of the group (Karali \& Aydemir, 2018).

Additionally, Goodlad (1984) stated that in traditional teacher-centred classes, less than 20\% of class time is spared for student language production. Moreover, each student does not get enough chances to speak and practise the language with each other, whereas, in cooperative learning classrooms, $80 \%$ is devoted to activities that include talking and practising (Daloğu, 2010). Besides, Jiang (2014) started his study by asserting that traditional English-teaching methods, which concentrate on reading, grammar and translation, should be improved to cope up with learners' needs, namely, communicative competence and skills when using a language. The same significant finding of the study was also reported in Taheri's (2014), Mothe's (2000) and Daloğu's (2010) studies.

On the other hand, Nguyen and Khuat (2003) reported that the traditional methods of learning vocabulary were not sufficient, and students preferred to learn vocabulary in a relaxed and fun environment such as vocabulary games. In this case, the students will be 
communicatively involved in classroom activities, particularly shy, bored and weak students (Taheri, 2014). Moreover, traditional vocabulary instruction for many teachers involves inefficient methods as having students look words up in the dictionary, write definitions, and use words in sentences. He also added that word lists, teacher explanation, discussion, memorization, vocabulary books, and quizzes are often used in an effort to help students learn new words. Teachers should have knowledge of suitable techniques and methods used while teaching the vocabulary of global issues, and students can use suitable ones according to their needs, styles and interest. So, students' ability to acquire the English language can be noticed in using vocabulary inside and outside classrooms efficiently.

Learning cooperatively was a good chance for the participants to control their own learning processes in classrooms. In other words, the participants felt more responsible for the outcomes they reach. They learned and acquired the new words better due to the efficiency of the cooperative learning method. Positive interdependence occurred since the group members were linked to each other. So, they succeeded because they coordinated their efforts with each other. The findings correspond with the results in AlMashjari's (2012) study which found that cooperative learning positively affected significantly on the participants' English proficiency, and the students themselves had a positive attitude towards cooperative learning and a higher motivation to learn English. As a matter of fact, Khan and Akhtar (2017) asserted that the cooperative learning method is considered as one of the most effective student-centred methods used in teaching English language classes.

The steps of the cooperative learning process that occurred in the intervention phase will be explained in some details below to get a complete and clear picture of the experimental groups' performance. Jigsaw technique was applied in the experimental classroom, whereas traditional methods were applied in the control classroom.

First of all, many participants were not motivated to share in groups and to have the role of a teacher in classrooms. They faced difficulty to explain to each other. Moreover, some students did not do their shared work or prepared well; they just observed the others or kept silent. Afterwards and step by step, they started to share in their team noticeably. Some participants faced difficulty to pronounce, spell and to understand the meaning of new words, which led active students to help and encourage them from time to time. They also encouraged shy and distrust students who faced difficulty to share and to participate in the classroom. On the other hand, inactive participants gradually engaged and answered some of the required tasks confidently. Some advantages of social skills like leadership, decisionmaking, trust-building, communication and conflict-management skills were developed step by step. For instance, the participants divided themselves into groups and distributed duties, chose the leader and so on.

As a matter of fact, different social skills enhanced communication skills and language skills, which were also improved gradually. So, the participants listened to each other carefully, respected others' opinions and their responses were so respectful. In addition, shy students who faced difficulty to participate in the classroom became more confident with their group members. It was also observed that positive interdependence occurred since the group members were linked to each other. Thus, they succeeded because they coordinated their efforts with each other. Additionally, increased autonomy, cognitive growth and productivity were also developed that led the participants to control their own learning processes very 
well. In the intervention phase, in fact, cooperative learning made students feel more motivated, interested and encouraged and the classroom had a relaxed and comfortable atmosphere. Group work is more effective and significant than individual work; consequently, the members felt free to express their opinions and ideas, and respect for each other.

In fact, the participants had a good opportunity to learn many social skills during cooperative learning activities and tasks. Social skills are defined as interpersonal skills, which learners need to be successful in the cooperation process. Daloğu (2010) claims that there is no social skills instruction in cooperative learning classes; however, students turn out to be more caring, helpful, and understanding of each other. The author also affirmed that there are close relationships between cooperative learning and language development. Thus, learners who are taught through cooperative learning are exposed to increased amounts of effective communication in both comprehension and production, using the language for academic and social functions. In fact, social skills are needed to have the ability to complete a variety of tasks and exercises in a cooperative lesson. Social skills include leadership, decision-making, trust-building, communication, conflict-management skills, and so on. Students should realize that they can learn the social skills to work more effectively with others and teachers should use those skills to motivate learners during the cooperation. So, the academic performance of students promotes step by step. Teachers should pay more attention to encourage social skills in classrooms, so the group members' relationships are more positive since working together is not always easy.

In short, cooperative learning approach in the classroom raises learners' awareness about the importance of working together to carry out responsibilities and assume active roles in group work so that they complete the required tasks and activities concerning vocabulary knowledge accurately. In other words, using the cooperative learning method in classrooms may affect greatly the vocabulary of global issues knowledge on ESL/EFL students.

\section{Conclusion}

The study concludes that cooperative learning can contribute to cognitive development, increase autonomy, help in time management, and maintain productivity. In addition, cooperative learning contributes to learners' interaction (face-to-face interaction), communication skills, social skills and language skills. It also provides positive interdependence, productive knowledge, and individual accountability which are developed gradually. In addition, cooperative learning contributes to creating natural, interactive contexts in which learners have authentic reasons for listening to one another, asking questions, clarifying issues, and re-stating points of view. Cooperative learning method should be integrated into English language classrooms to improve the growth and productive knowledge of students and to promote students' achievement.

\section{References}

Allahyar, N., \& Nazari, A. (2012). Potentiality of Vygotsky's Sociocultural Theory in exploring the role of teacher perceptions, expectations and interaction strategies. WoPaLP, 6.

AlMashjari, A. K. (2012). The effectiveness of cooperative learning on EFL proficiency: A case study of grade ten female classroom in the New Developed High School Project 
in Riyadh, Saudi Arabia. (Unpublished Master dissertation). King Saud University Deanship, Saudi Arabia.

Almulla, M. (2017). An investigation of cooperative learning in a Saudi high school: A case study on teachers' and students' perceptions and classroom practices. (Unpublished doctoral dissertation). University of Leicester.

Alrayah, H (2018). The effectiveness of cooperative learning activities in enhancing EFL learners' fluency. English Language Teaching, 11(4), ISSN 1916-4742 E-ISSN 19164750 Published by Canadian Center of Science and Education. http://doi.org/10.5539/elt.v11n4p21

Azzioui, A. (2016). The effect of LT cooperative learning model and teacher's feedback on EFL students' writing: The case of second year students of English at the Mentouri Brothers University, Constantine. (Unpublished doctoral dissertation), University of Mentouri Brothers, Algeria.

Bilen. D. (2015). The effects of cooperative learning strategies on vocabulary skills of 4th grade students. (Unpublished Master dissertation), Ufuk University, Ankara.

Daloğu, A. (2010). Cooperative learning and vocabulary retention. ORTESOL Journal, 28(2010), 15-21.

Dimitrov, D. M., \& Rumrill, P. D. (2014). Pretest-posttest designs and measurement of change. 507 White Hall, College of Education, Kent State University, Kent. 159-165, $\mathrm{OH}$ 44242-0001, USA. https://www.researchgate.net/publication/10826237

Dornyei, Z. (2007). Research methods in applied linguistics, quantitative, qualitative, and mixed methodologies. Oxford: Oxford University Press.

Erfani, S. M. (2012). The rationale for introducing 'global issues' in English textbook development: Theory and practice in language studies. Academy Publisher Manufactured in Finland, 2(11), 2412-2416. https://doi.org/10.4304/tpls.

Erfiani, Y. P., \& Neno, H. (2018). The effect of Jigsaw method to improve EFL students' vocabulary ability. Metathesis: Journal of English Language Literature and Teaching, 2(2), 171 - 183. DOI: 10.31002/metathesis.v2i2.695

Gairns, R., \& Redman, S. (1986). Working with words: A guide to teaching and learning vocabulary. Cambridge: Cambridge University Press.

Graves, M. F., \& Slater, W. H. (1987). The development of reading vocabularies in children from three social, economic, and linguistic settings: A preliminary report. Paper presented at the American Educational Research Association Annual Meeting. Washington, D.C.

Harmer, J. (2004). How to teach writing in the language classroom. England: Pearson Education Limited.

Hausfather, S. J. (1996). Vygotsky and schooling: Creating a social context for learning. Action in Teacher Education, 18(2), 1-10. https://doi.org/10.1080/01626620.1996.10462828

Inka, L., \& Niina, S. (2013). Global education from a teacher's perspective. (Unpublished Bachelor dissertation). Laurea University of Applied Sciences.

Jahromi, L. K., \& Marzban, A. (2015). A critical review of common vocabulary learning strategies in Iranian EFL classrooms. Journal of Applied Linguistics and Language Learning, 1(1), 30-36. https://doi.org/10.5923/j.jalll.20150101.05.

Jiang, X. (2014). Vocabulary learning through the use of the picture-word inductive model for young English learners in China: A mixed methods examination using cognitive load theory. (Unpublished doctoral dissertation). Florida International University, Miami, Florida. 
Johnson, D. W., \& Johnson, R. T. (1999). Learning together and alone: Cooperative, competitive, and individualistic learning (5th ed.). Boston: Allyn and Bacon.

Kagan, S. (1999). Cooperative learning: Seventeen pros and seventeen cons plus ten tips for success. Kagan Online Magazine. San Clemente, CA: Kagan Publishing. 21-29. www.KaganOnline.com

Karali, Y., \& Aydemir, H. (2018). The effect of cooperative learning on the academic achievement and attitude of students in mathematics class. Educational Research and Reviews,13(21), 712-722. DOI: 10.5897/ERR2018.3636

Khan, A., \& Akhtar, M. (2017). Investigating the effectiveness of cooperative learning method on teaching of English grammar. Bulletin of Education and Research, 39(1), 1-16. https://doi.org/10.30998/scope.v2i02.2458

Klapwijk, N.M. (2015). $\mathrm{EMC}^{2}=$ Comprehension: A reading strategy instruction framework for all teachers. South African Journal of Education, 35(1), 1-10. https://doi.org/10.15700/201503062348.

Lee, S. W. (2018). Pulling back the curtain: Revealing the cumulative importance of highperforming, highly qualified teachers on students' educational outcome. Educational Evaluation and Policy Analysis, 40(3)016237371876937 https://doi.org/10.3102/0162373718769379.

Lopes, I. (2012). Global issues: Educator's guide. National Film Board of Canada.

Mandal, R. R. (2011). Cooperative Learning Strategies to Enhance Writing Skills. International Journal of Instruction, 12(1),1399-1412. DOI: 10.29333/iji.2019.12189a

Margana, M. (2016). Voices of English teachers and students on blended culture as a model of English language teaching and learning at vocational high schools in Yogyakart. Mediterranean Journal of Social Sciences, 7(3), 459-466. https://doi.org/10.5901/mjss.2016.v7n3

Mothe, P. S. (2000). Innovative techniques of teaching vocabulary at the intermediate level in the second language classroom. Adarsh Senior College, Omerga Dist. Osmanabad (MS), India. Retrieved from http://journalpro.ru/articles/innovative-techniques-ofteaching-vocabulary-at-the-intermediate-level/

Nation, I. S. P. (2001). Learning vocabulary in another language. Cambridge: Cambridge University Press.

Nation, I., \& Webb, S. (2011). Researching and analyzing vocabulary. Boston, MA: Heinle, Cengage Learning.

Oxford, R. L. (2014). Cooperative learning, collaborative learning, and interaction: Three communicative strands in the language classroom. The Modern Language Journal, 81(4), 443-456. https://doi.org/10.1111/j.15404781.1997.tb05510.x

Pratama, H., \& Yuliati (2016). Global education in English classroom: Integrating global issues into English language teaching. International Journal of Social Science and Humanity, 6(9), 719-722. https://doi.org/10.18178/ijssh.2016.6.9.739.

Richards, J. C., \& Rodgers, T. S. (2001). Approaches and methods in language teaching. (2nd ed.). Cambridge: Cambridge University Press.

Samuels, S. J. (1994). Toward a theory of automatic information processing reading, revisited. In R. B. Ruddell, M. R. Ruddell, \& H. Singer (Eds.), Theoretical Models and Processes of Reading (4th ed.). (pp. 816-837). Newark, DE: International Reading Association. 
Schmitt, N. (2008). Review article: Instructed second language vocabulary learning. Language teaching research, 12(3), 329-363. http://dx.doi.org/10.1080/2331186X.2016.1252177

Sciamarelli, M. (2017). Should language teachers avoid global issues when teaching? Voices Magazine, 04 October 2017 - 18(18). https://www.britishcouncil.org/voices-magazine

Shabani, K. (2016). Applications of Vygotsky's sociocultural approach for teachers' professional development. Cogent Education, 3(1252177), 1-10. http://dx.doi.org/10.1080/2331186X.2016.1252177

Slavin, R. E. (1995). Cooperative learning theory: Research and practice. Massachusetts: Simon \& Schuster, Inc.

Taheri. M. (2014). The effect of using language games on vocabulary retention of Iranian elementary EFL learners. Journal of Language Teaching and Research, 5(3) 544-549. https://doi.org/10.4304/jltr.5.3.544-549

Terry, F. (2018). Keeping students engaged through cooperative learning activities to improve academic achievement in grammar and vocabulary. (Unpublished Master dissertation). Universidad de Piura.

Ünal, N. (2008). Pre-service teachers' perceptions toward global versus local environmental issues (Unpublished Master dissertation). Middle East Technical University.

Vygotsky, L.S. (1963). Learning and mental development at school age. Cambridge, MA: MIT Press.

Vygotsky, L.S. (1978). Interaction between learning and development. In M. Cole, V. JohnSteiner, S. Scribner, \& E. Souberman (Eds.), Mind in society: The development of higher psychological processes. (pp.79-91). Cambridge, MA: Havard University Press. 335.

Yavuz, O., \& Arslan, A. (2018). Cooperative learning in the acquisition of the English language skills. European Journal of Educational Research, 7(3), 591 - 600. Retrieved from http://www.eu- jer.com/ 